\title{
Effects of drought and nutrient deficiency on grafts originating from sound and shaken sweet chestnut trees (Castanea sativa Mill.)
}

\author{
Celestin Mutabaruka ${ }^{(1)}$ \\ Hadrian F Cook ${ }^{(2)}$, \\ G Peter Buckley ${ }^{(3)}$
}

\begin{abstract}
Scions taken from felled, shaken or sound sweet chestnut trees (Castanea sativa Mill.) were grafted and grown for one year in a polythene tunnel in order to compare their responses to water and nutrient stresses. Phenological characteristics of the original trees were strongly reproduced in the grafts grown both in this controlled environment and later on in the field. Grafts originating from shaken trees flushed up to six days later, senesced earlier and produced larger spring vessels. Artificially imposed drought reduced stomatal densities by $5.6 \%$ and xylem vessel diameters by up to $35 \%$. Fertiliser additions significantly increased stem increments and promoted earlier flowering, with hermaphrodite flowering filaments more common in grafts from shaken trees. It is considered that, because of their larger spring vessels, shaken trees may be more vulnerable to cavitation and therefore to drought, even though moisture stress is mitigated by some plasticity in earlywood vessel diameter.
\end{abstract}

\section{Keywords: Shake Defect, Castanea Sativa, Moisture Stress, Soil Fertility}

may predispose such trees, while fluctuations in soil moisture, for example in gleyed soil profiles, are also thought to exacerbate shake in the similarly ring-porous Quercus robur and Q. petrea (Savill 1986). Summer drought stress is a major growth limitation affecting chestnut plantations in some parts of the Mediterranean (AlvarezAlvarez et al. 2010), where moisture stress can be mitigated by management treatments such as thinning, removal of competing vegetation or lengthening of the rotation (Rubio et al. 1997, 1999, Cutini 2001, Cañellas et al. 2004), thus giving more soil resources per tree. In England, Henman \& Denne (1992) recommended planting oak (Quercus spp.) on deep soils with good moisture retention to avoid shake.

Under moisture stress, the xylem vessels are more likely to cavitate and lose their hydraulic conductivity through leakage at the pit membranes (Christman et al. 2009, Markesteijn et al. 2011). A trade-off therefore exists between wide-diameter earlywood vessels that transport most water early in the growing season (Corcuera et al. ture stresses than sound trees. Low soll water availability on freely draining sites
2006) and the risk of embolisms occurring later during drought episodes. The wider vessels associated with shaken chestnut individuals may thus be more prone to blockage by cavitation (Mutabaruka et al. 2005), although Sperry et al. (1994) found that some ring-porous species could tolerate cavitation or rely on new xylem production to restore hydraulic conductance. Furthermore, vessel size has been shown to acclimate to the availability of spring and summer precipitation in Quercus robur (Gárcia-González \& Eckstein 2003). Similar responses in the Mediterranean region have been found in both the diffuse-porous Q. ilex (Corcuera et al. 2004, Campelo et al. 2010) and the ring-porous Q. pyrenaica (Corcuera et al. 2006).

Shake may also be related to shortage of nutrients on the poor soils that commonly support chestnut plantations. Ranger \& Colin-Belgrand (1996) reported that decreasing the chestnut rotation length might deplete forest soil nutrients, a conclusion also reached by Rubio \& Escudero (2003). In Britain, Rackham (2003) pointed out that continual coppicing cycles of 8-30 years, removing 2-4 dry tones ha ${ }^{-1} \mathrm{yr}^{-1}$, might result in net nutrient export. However, in a fertilization experiment conducted at Kings forest in Kent, England, Evans (1986) reported no growth increases of chestnut coppice. Here the addition of lime significantly depressed growth, but small significant increases in foliar phosphate levels resulted from the addition of mineral phosphate.

However, responses to fertiliser on poor substrates may be significant. In former agricultural soils, Alvarez-Alvarez et al. (2010) found superior yields of plantations of Castanea sativa and the hybrid C. $\times$ coudercii where deeper profiles and the sup- 


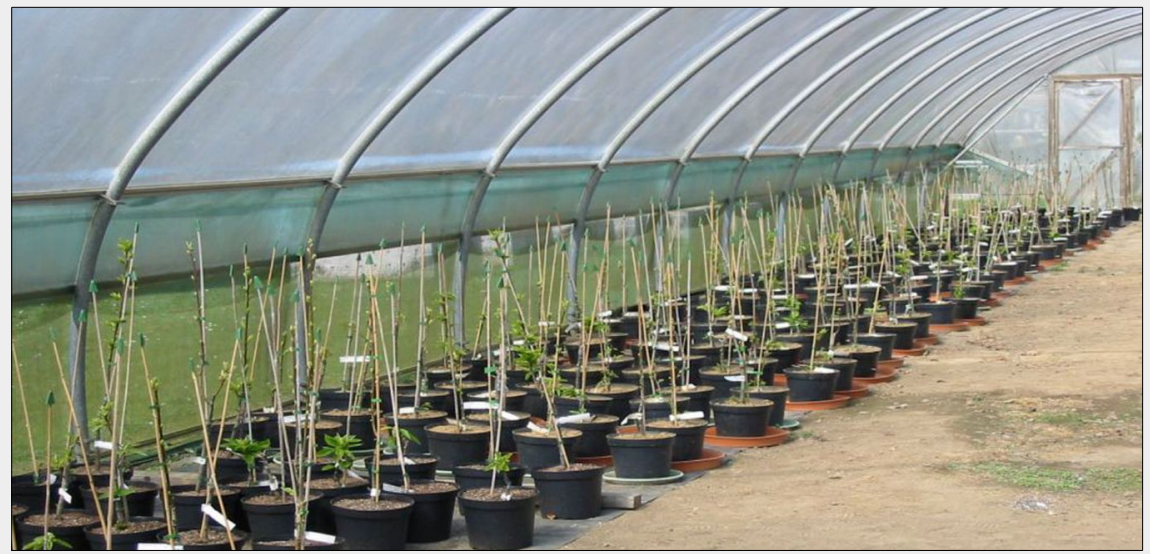

Fig. 1 - Layout of the pot experiment in a polythene tunnel, using one year-old grafted saplings, either of shaken or sound origin.

plies of available phosphorus, $\mathrm{Ca}$ and $\mathrm{K}$ were greater than in forest soils. Laroche et al. (1997) believed that calcium, an important element stabilising the middle lamella of cell walls, might be implicated in chestnut ring shake. In a glasshouse experiment using as a growth medium the $\mathrm{C}$ horizon of a mesotrophic brown soil, they found that one-year chestnut trees were able to grow for at least two years on this impoverished material. NPK fertiliser improved growth, as did further additions of calcium and magnesium, but liming did not depress growth. Fonti et al. (2002a) suggested that shake might be due to difficulties in calcium absorption, rather than the absolute amount of calcium.

Clearly, drought and nutrient treatments cannot be applied directly to trees growing in the field where their shake status is yet unknown. Instead, this investigation took grafts from trees known to be shaken or sound and subjected them to controlled environmental conditions. The specific questions were: $(I)$ is the growth of sweet chestnut scions influenced by their background and origin, or by stressed soil conditions such as low moisture and nutrients, or both? (ii) Could the growth responses and characteristics of the trees be helpful to foresters in identifying those that might be susceptible to shake?

\section{Methods}

Scions for grafting were taken from the upper crown of selected shaken or sound chestnut trees at five field sites in Kent, England, during March and April 2002: Brickhouse $\left(51^{\circ} 18^{\prime} \mathrm{N}, 1^{\circ} 5^{\prime} \mathrm{E}\right)$, Godinton $\left(51^{\circ}\right.$ $\left.9^{\prime} \mathrm{N}, 0^{\circ} 50^{\prime} \mathrm{E}\right)$, Three Wents $\left(51^{\circ} 5^{\prime} \mathrm{N}, 0^{\circ} 42^{\prime}\right.$ E), Larkey Valley $\left(51^{\circ} 15^{\prime} \mathrm{N}, 1^{\circ} 2^{\prime} \mathrm{E}\right)$ and Postling $\left(51^{\circ} 7^{\prime} N, 1^{\circ} 4^{\prime} E\right)$. Shake was confirmed by observing $5 \mathrm{~cm}$ thick green discs, cut from the base of each tree. These were mostly coppice stems but also included some maidens and were of differing age, ranging from 32 to 102 years and from 22$86 \mathrm{~cm}$ diameter at breast height $(1.3 \mathrm{~m}$ above ground). The scions were approximately $10-15 \mathrm{~cm}$ long, containing on ave- rage five buds. They were immediately dispatched to Horticulture Research International (HRI), East Malling, for grafting on to commercial nursery seedling stock.

After a season's growth at HRI East Malling, the grafts were re-potted into $25 \mathrm{~cm}$ diameter, 7.5 litre pots in an unheated polythene tunnel at the Wye Campus of Imperial College in the winter of 2003 (Fig. 1). Plastic saucers were placed underneath to conserve water and nutrients. Of 288 grafts, 90 from each category (shaken and sound) were selected from the mid-size range. The growing medium, an infertile, acidic sandy silt loam (Tab. SM1 in Appendix 1) was taken from the top $25-30 \mathrm{~cm}$ of the profile of a field at Godinton Park $\left(51^{\circ} 9^{\prime}\right.$ $\left.\mathrm{N}, \mathrm{O}^{\circ} 51^{\prime} \mathrm{E}\right)$. Large stones and weeds were removed by hand, and the soil thoroughly mixed.

In mid-March $15^{\text {th }} 2003$, five pots containing the re-potted grafts were soaked in a water- filled container and saturated for 45 hours. The pot surface was covered with black polythene to prevent evaporation and afterwards allowed to drain. Field capacity was determined after the third day, when Time Domain Reflectometry (TDR) indicated an average of 35\% volumetric water content. After 5 days without watering, the plants started to wilt at TDR readings of $10-11 \%$ volumetric water content; thereafter, $11 \%$ volumetric water content was taken as the critical baseline to avoid wilting and plant death.

\section{Experimental design}

The experiment was a completely randomised design, with three levels of moisture stress and three of NPK nutrients applied to 10 replicate grafts of either sound or shaken trees. There were thus 18 treatments and 180 experimental units.

Three soil moisture treatments were applied. Control grafts received no water stress and were maintained at field capacity throughout. Medium water stress was applied at $19-27 \%$ TDR and high stress at 11 $19 \%$ volumetric water content. Tap water was applied to maintain each of these three regimes every 2-5 days, depending on the weather, and triggered by soil moisture levels indicated by continuous TDR readings. The TDR instrument (Soil Moisture Equipment Corp., Santa Barbara, CA, USA) used two horizontally inserted waveguides $7 \mathrm{~cm}$ from the bottom of the pot; $40 \%$ of all replicates had wave-guides inserted.

Three nutrient levels were applied once to the pot surfaces as Growmore mini granules (an NPK 7:7:7 fertiliser) in late March 2003. The highest level of $4.94 \mathrm{~g}$ per pot was the equivalent of $23.8 \mathrm{~kg} \mathrm{~N}, 8.8 \mathrm{~kg} P$ and $21.4 \mathrm{~kg} \mathrm{~K} \mathrm{ha}^{-1}$, while the medium level had half this amount (2.47 g per pot) and the control had no applied fertiliser.

Grafts were grown in treatments for a full growing season in the polythene tunnel. Flushing times were noted between March $15^{\text {th }}$ and May $31^{\text {st }}$, with assessments carried out every other day, using the following scores:

- 0 : buds closed;

- 1: $<50 \%$ of buds breaking;

- 2: c. $50 \%$ of buds breaking;

- 3: all buds breaking;

- 4: unexpanded leaves visible at c. $50 \%$ of bud sites;

- 5: unexpanded leaves visible at all bud sites;

- 6: leaves half expanded;

- 7: leaves fully expanded.

Leaf retention at the end of the growing season was also observed over a period of 30 days from October $10^{\text {th }}$ to November $10^{\text {th }}$, every five days, counting all remaining leaves on the grafts. The percentage of leaf fall was calculated from the difference between the first and last counts.

Stem volume increments were calculated at the beginning and the end of the experiment, i.e., in March and October respectively. Leaf areas were assessed in midAugust, when two mature leaves were taken from the mid-crown of the leading graft shoot, using a leaf area meter (DeltaT Devices, Burwell, Cambridge, UK). In the same month stomatal densities were determined from two mature leaves, drawn from the mid-crown of two randomly selected grafts per treatment, using dental silicone rubber painted with nail varnish.

Flowering characteristics were recorded in June and included flower development, types of flowers (whether hermaphrodite or not), catkin length and filament length, fruiting and vessel size. Fruiting was assessed at the end of the growing season. Fruit diameters were grouped into three sizes, $\geq 6 \mathrm{~cm}, \geq 3-<6 \mathrm{~cm}$, and $<3 \mathrm{~cm}$ in diameter.

At the conclusion of the experiment, in the winter of 2004, 165 grafts consisting of approximately equal numbers of shaken and sound trees, were planted outside into a nearby experimental plot and spaced 1.5 $\mathrm{m}$ apart, in a fertile, silty clay loam soil. Twigs from 40 of these grafts were then collected after one growing season in November 2004, to assess the annual rings 
formed in 2003 and 2004. These consisted of equal numbers of both shaken and sound origins and represented high and non-water stressed treatments in the original high-nutrient regime only. Xylem vessel diameters in the spring vessels were then determined microscopically from microtomed twig sections, stained with Safranin O, Fast Green and Crystal Violet (Gerlach 1969).

Finally, leaf flushing scores of leaves on trees growing in the outdoor experimental plot were recorded on May $3^{\text {rd }} 2008$ and again on May $6^{\text {th }} 2014$.

\section{Statistical analysis}

The completely randomised experimental design was tested using the Analysis of Variance (ANOVA) for all main growth parameters, except for $t$-tests on vessel sizes formed respectively in 2003 and 2004. Flushing scores in 2008 and 2014 also used $t$-tests. The potential effects of physiological age on graft performance were tested using a Multivariate ANOVA or MANOVA (Field 2000).

Linear regression was applied to examine the relationship between vessel diameter and physiological tree age.

\section{Results}

Generally, grafts taken from sound trees showed superior performance to those of shaken origin, the relative differences depending on the level of water stress and nutrients applied.

\section{Flushing and leaf retention}

Flushing periods from sound or shaken trees, stages 0-1 (beginning), 0-4 (mid-flushing) and the total period (0-7) were significantly different. The ANOVA confirmed that sound tree grafts flushed earlier than shaken ones $(p<0.01)$, used fewer days to reach mid-flushing stage (13.6 vs. 19.6 days, $\mathrm{p}<0.001)$ and completed all flushing stages within 23 days, at least three days earlier $(p<0.001$ - Fig. 2a). Grafts growing in the highest fertiliser regime also flushed earlier than unfertilised controls and had shorter flushing periods $(p<0.001)$. Water stress reduced leaf retention generally (Tab. 1). Grafts from shaken trees lost their leaves sooner $(26.3 \%)$ but had little effect on grafts from sound ones $(44.6 \%, p=<0.001-$ Fig. 2b).

In 2008 and 2014 flushing stage scores were again used to compare the performance trees growing outside in the experimental plot. In 2008, four years after their removal from the polythene tunnel, trees of sound origin still flushed earlier than shaken trees (mean scores: 3.23 and 2.59, respectively $-\mathrm{p}<0.05, \mathrm{n}=75$ ). In 2014, after 11 years, taken in a slightly earlier growing season, the flushing scores were 5.19 for "sound" and 4.23 for "shaken" trees $(p<0.01, n=69)$.

\section{Overall stem increment}

The average stem increment of grafts

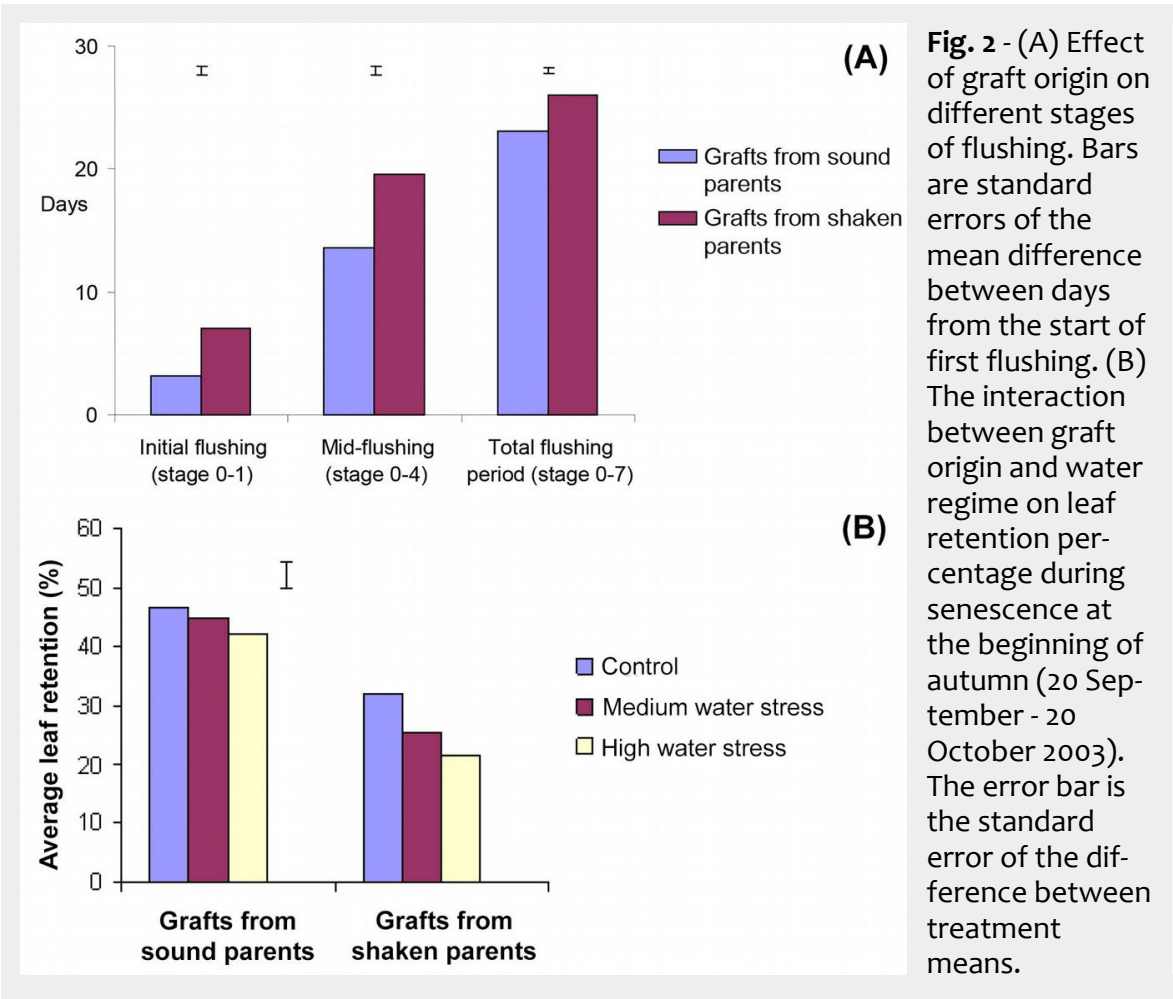

Tab. 1 - Effects of different watering regimes on graft leaf area, leaf retention, stomatal density and fruiting during the growing season. Fruit sizes: (category 1): large fruits (diameter $\geq 6 \mathrm{~cm}$ ); (category 2 ): medium fruits $(3 \mathrm{~cm} \leq$ diameter $<6 \mathrm{~cm}$ ); (category 3 ): small fruits (diameter $<3 \mathrm{~cm}$ ).

\begin{tabular}{lrrrrrr}
\hline \multirow{2}{*}{ Variables } & \multicolumn{2}{c}{ Water stress treatment } & \multirow{2}{*}{ P } & \multirow{2}{*}{ SED } & \multirow{2}{*}{ LSD } \\
\cline { 2 - 5 } & None & Medium & \multicolumn{1}{c}{ High } & & & \\
\hline Leaf area $\left(\mathrm{cm}^{2}\right)$ & 73.60 & 70.40 & 70.50 & 0.065 & 3.380 & 6.690 \\
Stomatal density mm ${ }^{-2}$ & 165.25 & 162.08 & 156.08 & 0.001 & 2.253 & 4.590 \\
Number of female flowers & 0.91 & 0.26 & 0.49 & 0.061 & 0.271 & 0.539 \\
Number of fruits category 1 & 1.77 & 1.37 & 0.93 & 0.106 & 0.387 & 0.784 \\
Number of fruits, category 2 & 4.68 & 1.51 & 1.06 & $<0.001$ & 0.728 & 1.474 \\
Number of fruits, category 3 & 2.29 & 4.87 & 2.71 & 0.024 & 0.960 & 1.946 \\
Total number of fruits & 8.75 & 7.75 & 4.72 & $<0.001$ & 1.018 & 2.066 \\
Leaf retention \% & 38.44 & 36.12 & 31.73 & $<0.001$ & 1.576 & 3.116 \\
(10 October - 10 November 2003) & & & & & & \\
\hline
\end{tabular}

Tab. 2 - Effect of nutrient regime on flushing, leaf area, leaf petiole length and stem increment of grafts during the growing season.

\begin{tabular}{|c|c|c|c|c|c|c|}
\hline Variables & $\begin{array}{c}\text { NPK } \\
\left(4.94 \mathrm{~g} \mathrm{pot}^{-1}\right)\end{array}$ & $\begin{array}{c}\text { NPK } \\
\left(2.47 \mathrm{~g} \mathrm{pot}^{-1}\right)\end{array}$ & $\begin{array}{c}\text { No NPK } \\
\text { (control) }\end{array}$ & $\begin{array}{c}\mathrm{p}- \\
\text { value }\end{array}$ & SED & LSD \\
\hline Beginning of flushing (days) & 4.53 & 4.77 & 6.00 & $<0.001$ & 0.412 & 0.813 \\
\hline & 24.08 & 4.19 & 5.37 & $<0.001$ & 0.310 & 0.612 \\
\hline Leaf area $\left(\mathrm{cm}^{2}\right)$ & 72.40 & 68.00 & 64.10 & 0.052 & 3.380 & 6.690 \\
\hline Petiole length $(\mathrm{cm})$ & 1.98 & 1.82 & 2.01 & 0.029 & 0.075 & 0.149 \\
\hline Stem increment $\left(\mathrm{cm}^{3}\right)$ & 42.90 & 39.90 & 27.60 & $<0.001$ & 3.500 & 6.930 \\
\hline
\end{tabular}

Tab. 3 - Effects of graft origin, from sound or shaken trees, on flowering.

\begin{tabular}{lcrrrc}
\hline Variables & Sound & Shaken & p-value & \multicolumn{1}{c}{ SED } & \multicolumn{1}{c}{ LSD } \\
\hline Proportion of flowering grafts (\%) & 57.20 & 72.80 & 0.031 & 0.072 & 0.142 \\
Beginning of flowering (days) & 12.42 & 8.73 & $<0.001$ & 0.565 & 1.124 \\
Female flowers (number per graft) & 0.91 & 0.20 & 0.002 & 0.221 & 0.440 \\
Catkin length (cm) & 8.79 & 4.97 & $<0.001$ & 0.450 & 0.896 \\
Filament length (mm) & 3.54 & 3.08 & 0.017 & 0.191 & 0.380 \\
Flowers with hermaphrodite filaments & 0.10 & 0.55 & 0.003 & 0.146 & 0.290 \\
(number per graft) & & & & & \\
\hline
\end{tabular}


from sound or shaken trees was similar (39.1 $\mathrm{cm}^{3}$ and $34.5 \mathrm{~cm}^{3}$ ) and not significantly different $(\mathrm{p}=0.114)$ according to the analysis of variance. However, stem incre- ments of grafts from both origins were considerably increased by fertiliser treatments $(p<0.001)$ compared with unfertilised controls (Tab. 2). Stem increment
Tab. 4 - Effects of water regimes on flowering and fruiting in grafts of sound or shaken origin: mean figures per graft. Fruit sizes: (category 1): large fruits (diameter $\geq$ $6 \mathrm{~cm}$ ); (category 2): medium fruits $(3 \mathrm{~cm} \leq$ diameter $<6 \mathrm{~cm})$; (category 3 ): small fruits (diameter $<3 \mathrm{~cm}$ ).

\begin{tabular}{|c|c|c|c|c|c|c|}
\hline \multirow{2}{*}{ Parameter } & \multirow{2}{*}{ Water stress } & \multicolumn{2}{|c|}{ Graft origin } & \multirow{2}{*}{$\mathrm{p}$} & \multirow{2}{*}{ SED } & \multirow{2}{*}{ LSD } \\
\hline & & Sound trees & Shaken trees & & & \\
\hline \multirow{3}{*}{$\begin{array}{l}\text { Female flowers } \\
\text { (number) }\end{array}$} & None & 1.5 & 0.31 & \multirow[t]{3}{*}{0.073} & \multirow[t]{3}{*}{0.383} & \multirow[t]{3}{*}{0.762} \\
\hline & Medium & 0.26 & 0.27 & & & \\
\hline & High & 0.96 & 0.03 & & & \\
\hline \multirow{3}{*}{$\begin{array}{l}\text { Hermaphrodite } \\
\text { flowers (number) }\end{array}$} & None & 0.11 & 0.93 & \multirow[t]{3}{*}{0.074} & \multirow[t]{3}{*}{0.253} & \multirow[t]{3}{*}{0.503} \\
\hline & Medium & 0.03 & 0.55 & & & \\
\hline & High & 0.17 & 0.17 & & & \\
\hline \multirow{3}{*}{$\begin{array}{l}\text { Catkin length } \\
(\mathrm{cm})\end{array}$} & None & 7.95 & 5.47 & \multirow[t]{3}{*}{0.080} & \multirow[t]{3}{*}{0.78} & \multirow[t]{3}{*}{1.551} \\
\hline & Medium & 9.15 & 5.14 & & & \\
\hline & High & 9.27 & 4.28 & & & \\
\hline \multirow{3}{*}{$\begin{array}{l}\text { Fruits, category } \\
1 \text { (number) }\end{array}$} & None & 2.64 & 0.91 & \multirow[t]{3}{*}{0.014} & \multirow[t]{3}{*}{0.547} & \multirow[t]{3}{*}{1.109} \\
\hline & Medium & 1.3 & 1.44 & & & \\
\hline & High & 0.69 & 1.19 & & & \\
\hline \multirow{3}{*}{$\begin{array}{l}\text { Fruits, category } \\
2 \text { (number) }\end{array}$} & None & 6.15 & 3.21 & \multirow[t]{3}{*}{0.083} & \multirow[t]{3}{*}{1.029} & \multirow[t]{3}{*}{2.085} \\
\hline & Medium & 1.50 & 1.52 & & & \\
\hline & High & 1.11 & 1.02 & & & \\
\hline \multirow{3}{*}{$\begin{array}{l}\text { Fruits, category } \\
3 \text { (number) }\end{array}$} & None & 2.59 & 2 & \multirow[t]{3}{*}{0.076} & \multirow[t]{3}{*}{1.358} & \multirow[t]{3}{*}{2.752} \\
\hline & Medium & 2.91 & 6.83 & & & \\
\hline & High & 1.92 & 3.51 & & & \\
\hline \multirow{3}{*}{$\begin{array}{l}\text { Total fruits } \\
\text { (number) }\end{array}$} & None & 11.39 & 6.11 & \multirow[t]{3}{*}{$<0.001$} & \multirow[t]{3}{*}{1.442} & \multirow[t]{3}{*}{2.921} \\
\hline & Medium & 5.72 & 9.78 & & & \\
\hline & High & 3.71 & 5.72 & & & \\
\hline
\end{tabular}

Tab. 5 - Effects of nutrient regimes on flowering and fruiting in grafts of sound or shaken origin: mean figures per graft. Fruit sizes: (category 2): medium fruits $(3 \mathrm{~cm} \leq$ diameter $<6 \mathrm{~cm}$ ); (category 3): small fruits (diameter $<3 \mathrm{~cm}$ ).

\begin{tabular}{|c|c|c|c|c|c|c|}
\hline \multirow{2}{*}{ Parameter } & \multirow{2}{*}{ Nutrient Regime } & \multicolumn{2}{|c|}{ Graft origin } & \multirow{2}{*}{$\mathrm{p}$} & \multirow{2}{*}{ SED } & \multirow{2}{*}{ LSD } \\
\hline & & Sound trees & Shaken trees & & & \\
\hline \multirow{3}{*}{$\begin{array}{l}\text { Beginning of } \\
\text { flowering } \\
\text { (days) }\end{array}$} & NPK $\left(4.94 \mathrm{~g} \mathrm{pot}^{-1}\right)$ & 14.59 & 7.95 & \multirow[t]{3}{*}{0.041} & \multirow[t]{3}{*}{0.078} & \multirow[t]{3}{*}{1.947} \\
\hline & NPK $\left(2.47 \mathrm{~g} \mathrm{pot}^{-1}\right)$ & 11.86 & 9.00 & & & \\
\hline & No added NPK & 10.82 & 9.24 & & & \\
\hline Catkin & NPK $\left(4.94 \mathrm{~g} \mathrm{pot}^{-1}\right)$ & 7.67 & 5.25 & \multirow[t]{3}{*}{0.082} & \multirow[t]{3}{*}{0.780} & \multirow[t]{3}{*}{1.551} \\
\hline \multirow[t]{2}{*}{ length $(\mathrm{cm})$} & NPK $\left(2.47 \mathrm{~g} \mathrm{pot}^{-1}\right)^{\prime}$ & 9.17 & 4.93 & & & \\
\hline & No added NPK & 9.53 & 4.71 & & & \\
\hline \multirow{3}{*}{$\begin{array}{l}\text { Fruits, } \\
\text { category } 2 \\
\text { (number) }\end{array}$} & NPK $\left(4.94 \mathrm{~g} \mathrm{pot}^{-1}\right)$ & 1.75 & 2.65 & \multirow{3}{*}{0.017} & \multirow[t]{3}{*}{1.029} & \multirow[t]{3}{*}{2.085} \\
\hline & NPK $\left(2.47 \mathrm{~g} \mathrm{pot}^{-1}\right)$ & 2.49 & 1.98 & & & \\
\hline & No added NPK & 4.52 & 1.11 & & & \\
\hline Fruits, & NPK $\left(4.94 \mathrm{~g} \mathrm{pot}^{-1}\right)$ & 2.15 & 4.01 & 0.058 & 1.358 & 2.752 \\
\hline category 3 & NPK $\left(2.47 \mathrm{~g} \mathrm{pot}^{-1}\right)$ & 3.76 & 2.91 & & & \\
\hline (number) & No added NPK & 1.52 & 5.42 & & & \\
\hline
\end{tabular}

Tab. 6 - Interactions between water and nutrient regimes on flowering and fruiting of grafts. Fruit sizes: (category 2): medium fruits $(3 \mathrm{~cm} \leq$ diameter $<6 \mathrm{~cm}$ ); (category 3 ): small fruits (diameter $<3 \mathrm{~cm}$ ).

\begin{tabular}{|c|c|c|c|c|c|c|c|}
\hline \multirow{2}{*}{ Parameter } & \multirow{2}{*}{ Water stress } & \multicolumn{3}{|c|}{ NPK $\left(\mathrm{g} \mathrm{pot}^{-1}\right)$} & \multirow{2}{*}{ p } & \multirow{2}{*}{ SED } & \multirow{2}{*}{ LSD } \\
\hline & & $44.5 \mathrm{~g}$ & $2.47 \mathrm{~g}$ & Control & & & \\
\hline Petiole & None & 2.05 & 1.67 & 2.09 & 0.091 & 0.13 & 0.258 \\
\hline \multirow[t]{2}{*}{ length $(\mathrm{cm})$} & Medium & 2.00 & 1.87 & 2.07 & & & \\
\hline & High & 1.89 & 1.93 & 1.87 & & & \\
\hline Catkin & None & 6.31 & 6.72 & 7.10 & 0.010 & 0.955 & 1.9 \\
\hline \multirow[t]{2}{*}{ length $(\mathrm{cm})$} & Medium & 8.15 & 6.92 & 6.36 & & & \\
\hline & High & 4.92 & 7.5 & 7.9 & & & \\
\hline \multirow{3}{*}{$\begin{array}{l}\text { Fruits, } \\
\text { category } 2 \\
\text { (number) }\end{array}$} & None & 5.40 & 3.29 & 5.35 & 0.020 & 1.26 & 2.554 \\
\hline & Medium & 0.25 & 3.44 & 0.84 & & & \\
\hline & High & 0.95 & 0.02 & 2.26 & & & \\
\hline \multirow{3}{*}{$\begin{array}{l}\text { Fruits, } \\
\text { category } 3 \\
\text { (number) }\end{array}$} & None & 2.53 & 3.5 & 0.85 & 0.010 & 1.664 & 3.371 \\
\hline & Medium & 3.71 & 2.84 & 8.06 & & & \\
\hline & High & 3.00 & 3.66 & 1.49 & & & \\
\hline
\end{tabular}

growth was unaffected by water stress.

\section{Leaf area}

Mean leaf areas of grafts taken from sound trees $\left(76.50 \mathrm{~cm}^{2}\right)$ were significantly greater than from shaken ones $\left(59.80 \mathrm{~cm}^{2}\right.$; $\mathrm{p}<0.01)$. Leaves from fertilised grafts were only marginally larger $(p=0.052)$ and were unaffected by water stress $(\mathrm{p}=0.065-$ Tab. 2). However, petiole lengths were shorter in middle fertiliser treatment, contrasting with the others $(p=0.029)$. Water stress had little effect on leaf areas (Tab. 1).

\section{Stomatal density}

Stomatal densities were reduced under conditions of water stress ( $p=0.001-T a b$. 1 ), especially in the highly stressed treatment, where the average density was 156.1 $\mathrm{mm}^{-2}$, a $5.6 \%$ reduction compared with the control. The densities on leaves of grafts taken from sound trees $\left(163.8 \mathrm{~mm}^{-2}\right)$ was marginally greater than those shaken ones $\left(158.4 \mathrm{~mm}^{-2}, \mathrm{p}=0.020\right)$.

\section{Flowering and fruiting}

More than half of the grafts (59.4\%) flowered during the growing season. Significant differences were found between graft origin, with shaken origins having a greater tendency to flower, to flower earlier, and to produce a number of hermaphrodite filaments (Tab. 3), although these only accounted for $9 \%$ of the total. In contrast, grafts from sound trees had longer catkins and filaments and produced greater numbers of female flowers. Grafts from shaken trees produced larger numbers of small fruits ( $<3 \mathrm{~cm}$ diameter) than from sound trees (Tab. 4). The total number of fruits produced was greatest when grafts were grown at field capacity ( $<<0.001-$ Tab. 1$)$, mainly in sound-origin grafts, which also produced most large (category 1) fruits (Tab. 4).

Fertilised grafts flowered on average earlier $(p=0.005)$ and earlier still in grafts taken from shaken individuals (Tab. 5). Interestingly, there were more mediumsized (category 2 fruits) produced by sound grafts growing in unfertilised pots, but more such fruits on shaken grafts in fertilised pots. Some interactions between water and nutrient availability were difficult to interpret. Catkins were shorter in high water stress, high fertiliser treatments. There were more medium-sized fruits produced at low water stress, irrespective of fertiliser status, and more small fruits in unfertilised controls at medium water stress (Tab. 6).

\section{Vessel size}

The mean vessel diameters of grafts grown in 2003 with no water stress (0.048 $\mathrm{mm}$ ) was significantly greater than in stressed treatments $(0.031 \mathrm{~mm})$, confirmed by $t$-testing ( $p<0.001$ - Fig. 3$)$. With no water stress, the average vessel diameter of grafts from sound trees was significantly wider $(0.035 \mathrm{~mm})$ than those formed 
under stress ( $0.026 \mathrm{~mm}, \mathrm{p}<0.001-t$-test). A similar trend was observed with grafts of shaken origin (means of $0.054 \mathrm{~mm}$ compared with $0.037 \mathrm{~mm}, \mathrm{p}<0.001)$. Mean vessel diameter was always wider in shaken grafts: pooling water stress treatments, those from shaken trees $(0.046 \mathrm{~mm})$ were significantly narrower than from sound trees (0.030 mm, $p<0.001$ - Fig. 3).

Grafts grown outside in the experimental plot in 2004, where soil moisture was theoretically consistent, formed xylem vessels of similar diameter irrespective of water stress treatments applied a year earlier (Fig. 3). Once again, $t$-testing showed that average vessel diameters originating from shaken trees $(0.059 \mathrm{~mm})$ were significantly wider than those from sound trees ( 0.039 $\mathrm{mm}, \mathrm{p}<0.001)$. Vessel lumens developed outside during 2004 were also significantly wider than their 2003 counterpart: those from sound origins were 0.026 and 0.037 $\mathrm{mm}$ in 2003 and 2004, respectively ( $\mathrm{p}<$ 0.001 ), compared with 0.037 and $0.058 \mathrm{~mm}$ for plants from shaken trees $(p<0.001)$.

\section{Discussion}

\section{Physiological age of graft material}

As the incidence of shake tended to be greater in older trees (Mutabaruka et al. 2005), it was important to test whether responses to water and nutrients was influenced by the physiological age of grafts. The MANOVA analysis, however, showed only marginal effects on age on performance. Graft stem increment, leaf retention and most flowering and fruiting parameters were largely independent of original tree age. The observed differences between graft origins were therefore reliable for these parameters, but for vessel diameters formed in 2003 there was a tendency for stressed grafts from older trees to produce larger early vessels. When pooling water stress treatments, however, the regressions analysis showed vessel diameter to be independent of age, with shaken origins showing wider diameters (Fig. 4). Similarly, no relationship between vessel size and original tree age was found in 2004.

\section{Phenology}

In most respects the performance of grafts from sound trees was superior to that of shaken grafts, irrespective to the treatment. Grafts from sound trees flushed earlier, had marginally larger leaf areas, higher densities of stomata and retained their leaves for longer than those from shaken trees, generally agreeing with observations made on the original trees in the field in 2001 (Mutabaruka et al. 2005). Flushing scores taken in 2008 and 2014, four and 11 years respectively after the polythene tunnel experiment, showed that sound grafts still flushed earlier than shaken ones, implying that leaf phenology is under strong genetic control. Late flushing thus appears to be the most promising visual characteristic that foresters and
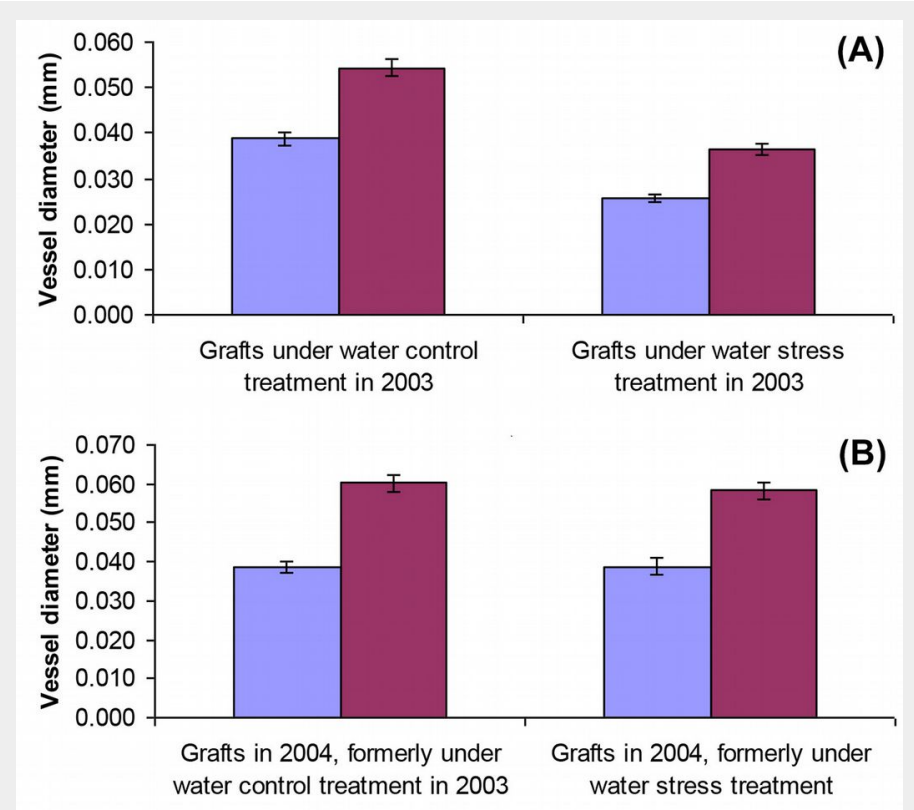

Fig. 3 - Comparison of mean earlywood vessel diameters in grafts from sound and shaken trees under control and water stress treatments in (A) 2003 and (B) in the same grafts in 2004, when no water stress was applied. Error bars are standard errors of the means (SE).

$\square$ Vessels of grafts from sound parents $\square$ Vessels of grafts from shaken parents

timber merchants could use to distinguish sound from shaken trees.

\section{Treatment responses}

Significant growth resulted from nutrient additions, with larger average leaf areas and stem increments, but with no major differences between grafts taken from shaken or sound trees. Although the general trend conflicts with findings by Evans (1986) of little fertiliser response in commercial chestnut coppices at Kings Wood, the soil medium in that case was relatively fertile loamy-clay plateau drift, unlike the growth medium used in this experiment. The contrast here is analogous to the superior growth of chestnut plantations on ex- agricultural, rather than forest soils described by Alvarez-Alvarez et al. (2010).

Flowering and fruiting also differed between sound and shaken graft origins. Flowering frequency was greater in shaken-origin grafts, which also flowered earlier and with a significantly greater number of hermaphrodite filaments. Water stress reduced the total number of their fruits (most notably in the middle and smallest size ranges), while fruiting tended to increase with added fertiliser. However, grafts from sound trees produced fewer flowers under water stress and least when nutrient and water stress was applied. The opposite occurred in shaken grafts, with more flowering occurring and giving rise to
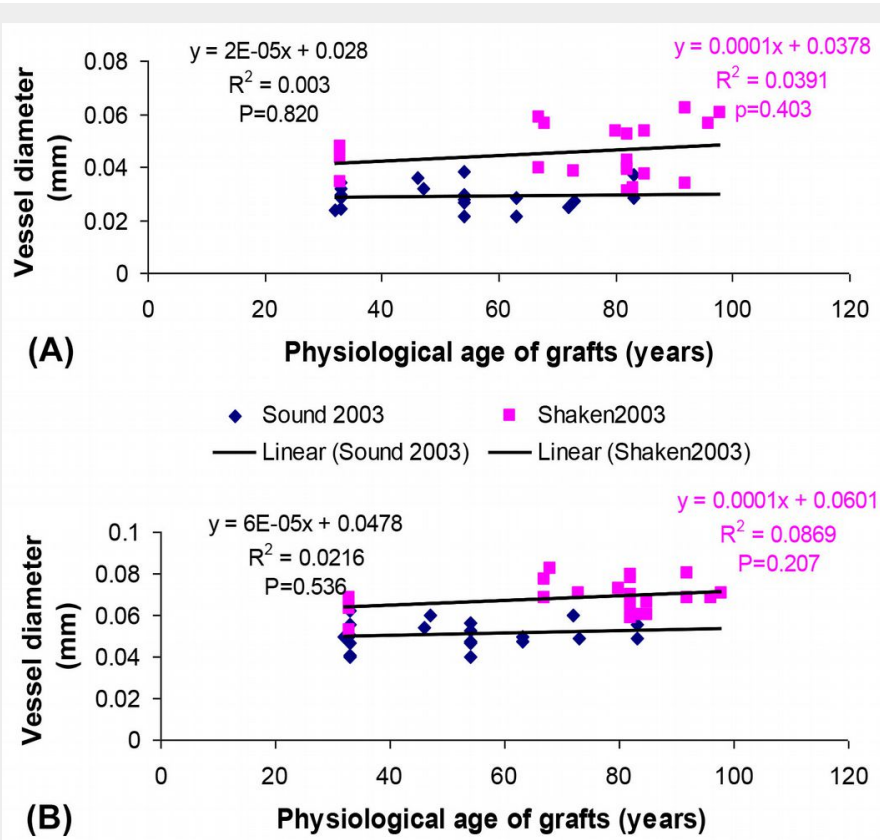

- Sound 2004 Shaken2004

_ Linear (Sound 2004) _ _ Linear (Shaken2004)
Fig. 4 - Relationship between vessel diameter and physiological age of grafts taken from sound and shaken trees, showing the consistently larger vessels in shaken grafts in (A) 2003 and (B) 2004, combining water stress treatments. 
medium-sized fruits when conditions were limiting. This suggests that shaken trees may be more tolerant of low fertility. In terms of visual cues, foresters may select against copious flowering in potentially shaken trees, but hermaphrodite flowers are probably too infrequent to be used as indicators.

The lack to response of the grafts to drought treatments suggests either innate tolerance, or that, by avoiding wilting, the lowest water regime was not severe enough. Water stress did reduce the number of stomata, presumably in response to drought, consistently with Salisbury \& Ross (1985) and Woodward (1987) who showed that the density is controlled by endogenous and environmental factors. Water stress also appeared to reduce vessel size, in agreement with observations by Sass \& Eckstein (1995) and Corcuera et al. (2004) on other tree species. While vessel sizes remained constant in the outside plot, the smaller diameter vessels observed under imposed drought treatments in the polythene tunnel indicated a plastic response to environmental conditions. However, wider diameter vessels always occurred in grafts from shaken trees, both inside and outside the controlled tunnel environment, contradicting the findings of Fonti et al. (2002b), who observed that in shake-prone stems of chestnut earlywood the vessels were neither more numerous nor wider.

\section{Conclusion}

Factors such as vessel diameter, flushing time, flowering type and flowering incidence appeared to be under strong genetic control in chestnut, of which late flushing is the most useful to foresters and timber merchants as a possible indicator of shake in standing trees. While there was evidence that the plant could control soil water stresses to an extent by reducing earlywood vessel sizes and leaf stomata densities, the differences in vessel diameter between shaken and sound tree origins remained, leaving the latter potentially more susceptible to cavitation during summer drought. Growth was enhanced by moderate levels of fertiliser on an infertile growth medium, with the grafts of shaken trees possibly less affected. The growth of both shaken and sound trees could potentially be improved either by fertiliser addition on poor soils, or by a more fertile situation.

\section{References}

Alvarez-Alvarez P, Díaz-Varela E, Cámara-Obregón A, Afif-Khouri E (2010). Relating growth and nutrition to site factors in young chestnut plantations established on agricultural and forest land in northern Spain. Agroforestry Systems 79: 291-301. - doi: 10.1007/s10457-010-9313z

Campelo F, Nabais C, Gutiérrez E, Freitas H, García-González I (2010). Vessel features of Quercus ilex L. growing under Mediterranean climate have a better climatic signal than tree- ring width. Trees 24: 463-470. - doi: 10.1007/ s00468-010-0414-0

Cañellas I, Del Río M, Roig S, Montero G (2004). Growth response to thinning in Quercus pyrenaica Wild. coppice stands in Spanish central mountain. Annals of Forest Science 61: 243-250. doi: 10.1051/forest:2004017

Christman MA, Sperry JS, Adler FR (2009). Testing the "rare pit" hypothesis for xylem cavitation resistance in three species of Acer. New Phytologist 182: 664-674. - doi: 10.1111/j.14698137.2009.02776.x

Corcuera L, Camarero J, Gil-Pelegín E (2004). Effects of a severe drought on Quercus ilex radial growth and xylem anatomy. Trees 18: 8392. - doi: 10.1007/s00468-003-0284-9

Corcuera L, Camarero JJ, Sisó S, Gil-Pelegrín E (2006). Radial-growth and wood-anatomical changes in overaged Quercus pyrenaica stands: functional responses in a new Mediterranean landscape. Trees 20: 91-98. - doi: 10.1007/so04 68-005-0016-4

Cutini A (2001). New management options in chestnut coppices: an evaluation on ecological bases. Forest Ecology and Management 141: 165-174. - doi: 10.1016/S0378-1127(00)00326-1 Evans J (1986). Nutrition experiments in broadleaved stands: II. Sweet chestnut and stored oak coppice. Quarterly Journal of Forestry 80: 95-104. [online] URL: http://www.cabdirect. org/abstracts/19860610835.html

Field A (2000). Discovering statistics using SPSS for Windows. SAGE publications, London, UK, pp. 512.

Fonti P, Macchioni N, Thibaut B (2002a). Ring shake in chestnut (Castanea sativa Mill.): state of the art. Annals of Forest Science 59: 129-140. doi: 10.1051/forest:2002007

Fonti P, Bräker O-U, Giudici F (2002b). Relationship between ring shake incidence and earlywood vessel characteristics in chestnut wood. IAWA Journal 23: 287-298. - doi: 10.1163/229419 32-90000304

Fonti P, Macchioni N (2003). Ring shake in chestnut: anatomical description, extent and frequency of failures. Annals of Forest Science 60: 403-408. - doi: 10.1051/forest:2003032

Fonti P, Frey B (2002). Is ray volume a possible factor influencing ring shake occurrence in chestnut wood? Trees 16: 519-522. - doi: $10.1007 /$ s00468-002-0193-3

Gárcia-González I, Eckstein D (2003). Climatic signal of earlywood vessels of oak on a maritime site. Tree Physiology 23: 497-504. - doi: 10.1093/ treephys/23.7.497

Gerlach D (1969). A rapid safranin-crystal violetlight green staining sequence for paraffin sections of plant materials. Stain Technology 44: 210-211.

Henman GS, Denne MP (1992). Shake in oak. Forestry Commission Research Division 4, Alice Holt, Farnham, UK, pp. 4.

Laroche A, Freyssac V, Rahmani A, Verger JP, Morvan H (1997). Growth and mineral content of young chestnut trees under controlled conditions of nutrition. Annales des Sciences Forestières 54: 681-693. - doi: 10.1051/forest:19970 708

Macchioni N, Pividori M (1996). Ring shake and structural characteristics of a chestnut (Castanea sativa Miller) coppice stand in northern
Piedmont (northwest Italy). Annales des Sciences Forestières 53: 31-50. - doi: 10.1051/forest: 19960103

Markesteijn L, Poorter L, Paz H, Sack L, Bongers $F$ (2011). Ecological differentiation in xylem cavitation resistance is associated with stem and leaf structural traits. Plant, Cell and Environment 34: 137-148. - doi: 10.1111/j.1365-3040.2010. 02231.x

Mutabaruka C, Woodgate GR, Buckley GP (2005). External and internal growth parameters as potential indicators of shake in sweet chestnut (Castanea sativa Mill.). Forestry 78: 175-186. - doi: 10.1093/forestry/cpio16

Rackham O (2003). Ancient woodland: its history, vegetation and uses in England. Castlepoint Press, Dalbeattie, UK, pp. 584.

Ranger J, Colin-Belgrand M (1996). Nutrient dynamics of chestnut tree (Castanea sativa Mill.) coppice stands. Forest Ecology and Management 86: 259-277. - doi: 10.1016/So378-1127(96) 03733-4

Rubio A, Escudero A, Gandullo JM (1997). Sweet chestnut silviculture in an ecological extreme of its range (Extremadura-Spain). Annals of Forest Science 54: 667-680. - doi: 10.1051/forest: 19970707

Rubio A, Gavilán R, Escudero A (1999). Are soil characteristics and understorey composition controlled by forest management? Forest Ecology and Management 113: 191-200. - doi: 10.1016/S0378-1127(98)00425-3

Rubio A, Escudero A (2003). Clear-cut effects on chestnut forest soils under stressful conditions: lengthening of time-rotation. Forest Ecology and Management 183: 195-204. - doi: 10.1016/ S0378-1127(03)00115-4

Salisbury FB, Ross CW (1985). Plant physiology. Wadsworth, Belmont, CA, USA, pp. 336. Sass U, Eckstein D (1995). The variability of vessel size in beech (Fagus sylvatica L.) and its ecophysiological interpretation. Trees 9: 247-252. doi: 10.1007/BF00202014

Savill PS (1986). Anatomical characteristics in the wood of oak (Quercus robur L. and Q. petraea Liebl.) which predispose trees to shake. Commonwealth Forestry Review 65: 109-116. [online] URL: http://www.jstor.org/stable/426080 66

Sperry JS, Nichols KL, Sullivan JEM, Eastlack SE (1994). Xylem embolism in ring-porous, diffuseporous, and coniferous trees of Northern Utah and Interior Alaska. Ecology 75: 1736-1752. - doi: $10.2307 / 1939633$

Vinciguerra V, Spina S, Luna M, Petrucc G, Romagnoli N (2011). Structural analysis of lignin in chestnut wood by pyrolysis-gas chromatography/mass spectrometry. Journal of Analytical and Applied Pyrolysis 92: 273-279. - doi: 10.1016/j.jaap.2011.06.009

Woodward FI (1987). Stomatal numbers are sensitive to increases in $\mathrm{CO}_{2}$ from pre-industrial levels. Nature 327: 617-618. - doi: 10.1038/327617 ao

\section{Supplementary Material}

Appendix 1 - Soil chemical properties of the growth medium.

Link: Mutabaruka_1572@supplo01.pdf 